\title{
THE DICHOTOMOUS SPECIES OF CODIUM IN BRITAIN
}

\author{
By Paul C. Silva \\ Department of Botany, University of Illinois, Urbana
}

(Plate I and Text-figs. I-5)

The name Codium tomentosum (or its nomenclatural synonym C. dichotomum) has been applied to dichotomous representatives of the genus in the British Isles ever since the genus was established by Stackhouse in 1797 . The purpose of this paper is twofold: to show that three distinct species are involved; and to clarify the nomenclature.

I am grateful to the directors and curators of the following herbaria for the loan of specimens: British Museum (BM); Royal Botanic Garden, Edinburgh (E); Farlow Herbarium, Harvard University ( $\mathrm{FH})$; University of Glasgow (GL); Royal Botanic Gardens, Kew (K); Rijksherbarium, Leiden (L); Linnean Society of London (LINN); University of Michigan (MICH); New York Botanical Garden (NY); University of Oxford (OxF); Muséum National d'Histoire Naturelle, Laboratoire de Cryptogamie, Paris (PC); Marine Biological Association, Plymouth ( $\mathrm{PL})$; Naturhistoriska Riksmuseet, Stockholm (S); Trinity College, Dublin (TCD); University of California, Berkeley (UC); United States National Museum(US). Liquid-preserved and dried material, which has been placed in the Herbarium of the University of California, was kindly provided by Dr Sheila Lodge, Dr Betty Moss, Dr Mary Parke, Dr Máirín de Valéra, and Dr M. A. Wilson. Special thanks are due to Dr Mary Parke for her sustained interest, encouragement, and help in this study.

Codium fragile (Sur.) Hariot subsp. atlanticum (Cotton) Silva, n.comb.

\section{(Text-fig. I)}

Codium mucronatum J. Ag. var. atlanticum Cotton, I9I2, p. II4, pl. VII; pl. VIII, figs. $3-5$.

C. fragile (Sur.) Hariot var. typicum O. C. Schmidt subvar. atlanticum (Cotton)

O. C. Schmidt, 1923, p. 47.

C. tomentosum Stackh. var. atlanticum (Cotton) Lily Newton, I93I, p. I06.

C. fragile (Sur.) Háriot f. atlanticum (Cotton) Levring, 1937, p. 34.

C. atlanticum (Cotton) De Valéra, I939, p. I2.

Thallus composed of one to several erect robust fronds arising from broad, spongy, basal disk; fronds $15-25(-50) \mathrm{cm}$ high, dichotomously branched (to 9 orders), dichotomies at times telescoped to give fastigiate appearance; 

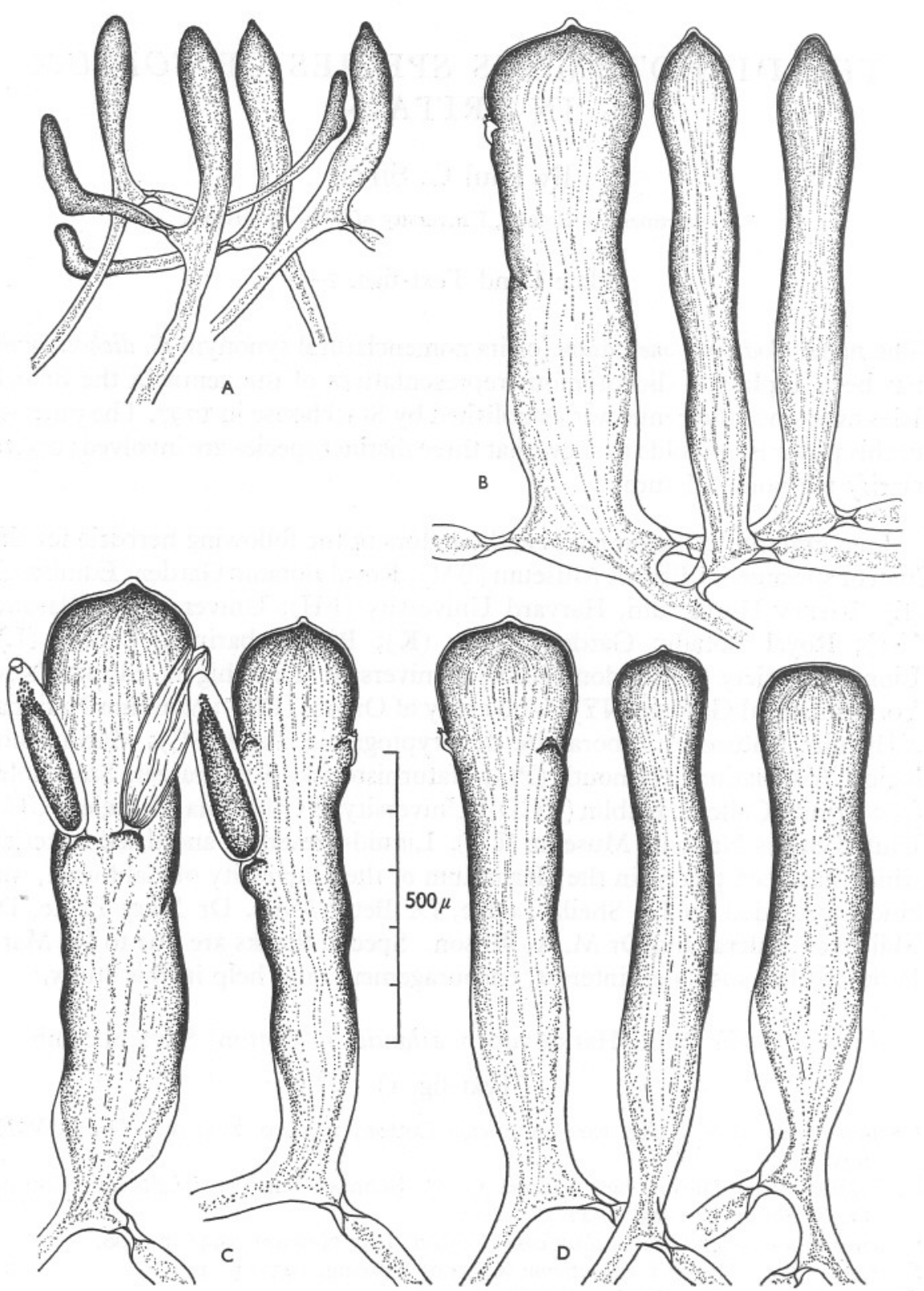

Text-fig. I. Codium fragile subsp. atlanticum. A, utricles from tip; B, utricles from base; c, D, utricles from middle of frond. A, B, D, Carna, de Valéra; C, Port St Mary, Lodge. 
branches terete (at times flattened at base), tapering from base (c. Io mm diam.) to apex (2.5-4 mm diam.). Utricles irregularly cylindrical or clavate, (I30-) I70-330 $\mu$ max. diam., 780-II00 ( - I200) $\mu$ long, usually $3-5 \times$ long as broad; apices slightly rounded, often terminating in a blunt (or occasionally sharp) point or umbo; wall of utricle $c . \mathrm{I} \cdot 5 \mu$ thick, thicker at apex $(-\mathrm{I} 2 \mu)$ and often prolonging point into mucron IO-I $4 \mu$ long. Hairs (or hair scars) common, one or two per utricle, borne $130-200 \mu$ below apex. Gametangia ovoid, oblong, or fusiform, $80-\mathrm{I} 30 \mu$ diam., $260-400 \mu$ long, one or two per utricle, each borne on protuberance near middle of utricle. Medullary filaments mostly $28-68 \mu$ diam.

Type. Rock pool, Roonah Point (opposite Clare Island), Co. Mayo, Eire, June I9ro, A. D. Cotton (K).

Geographic distribution. Western Ireland northward to western Scotland, Orkney Is., Isle of Man, Northumberland, Dorset, Norway.

Representative specimens examined. Ireland. Clare: Kilkee, Oct. I897, E. George (BM). Galway: Muigh Inis, Carna, Oct. I943, M. de Valéra. Mayo: Kinnacorra, Clare I., Aug. I9I I, A. D. Cotton (BM); Roonah Point, June igio, $A$. D. Cotton (K) (type). Sligo: Sligo Bay, July I850, Hennedy (GL). Donegal: Bundoran, July I850, W. H. Harvey (TCD). Antrim: Portrush, Oct. I858, Hennedy (GL); Giants Causeway, May I9I0, A. D. Cotton (K); Larne, Aug. I865, Mrs C. A. Fohnson (BM). Down: Tara Point, Ards Peninsula, Aug. I953, C. I. Dickinson (K). Isle of Man. Bradda Head, Port Erin, April I9I2, R. F. Harvey-Gibson (K); Port St Mary, May I950, S. Lodge. Scotland. ButE: Eilans, Cumbrae, Aug. I891, E. Batters (BM); Keppel, Cumbrae, Apr. I955, E. Conway (GL). ARgyll: Iona, June I826, R. K. Greville (E). ORKnEY: South Ronaldshay, Aug. I89I, G. W. Traill (BM); Pharay, Aug. I880, Boswell (E); Westray, Aug. I845 (TCD). Inverness: Mallaig, Aug. I949, E. Conway (GL). England. Northumberland: Berwick-upon-Tweed, Oct. 1949, B. Moss; Farne Is., Nov. 1952, B. Moss. Dorset: Swanage, Aug. I894, E. Batters (BM).

Codium fragile (Sur.) Hariot subsp. tomentosoides (van Goor) Silva, n.comb.

(Text-figs. 2, 3)

Codium mucronatum J. Ag. var. tomentosoides van Goor, 1923, p. I34, fig. I c.

Thallus as in C. fragile subsp. atlanticum. Utricles irregularly cylindrical or more often clavate, frequently with broad constriction at or just below middle, (105-) I65-325 (-400) $\mu$ max. diam., 550-1050 $\mu$ long, usually $2.5-5.5 \times$ long as broad; apices rounded-apiculate; wall of utricle c.I.5 $\mu$ thick, thicker at apex $(-\mathrm{I} 2 \mu)$, prolonging point into mucron up to $68 \mu$ long. Hairs (or hair scars) common, one or two per utricle, borne $160-260 \mu$ below apex. Gametangia ovoid, oblong, or fusiform, 72-92 $\mu$ diam., 260-330 $\mu$ long, 
one or two per utricle, each borne on protuberance near middle of utricle (410-560 $\mu$ below apex.) Medullary filaments mostly $26-68 \mu$ diam.

Type. Huisduinen, Netherlands, I900, Mrs F. L. Redeke-Hoek (specimen not located). In the absence of the holotype, I have selected as neotype a specimen from Helder, Netherlands, annotated by van Goor, in the possession of Prof. J. Heimans, Hugo de Vries Laboratorium, Amsterdam.

Geographic distribution. Southern England, Scotland (Argyll), Ireland (Cork) France, Netherlands, Scandinavia.
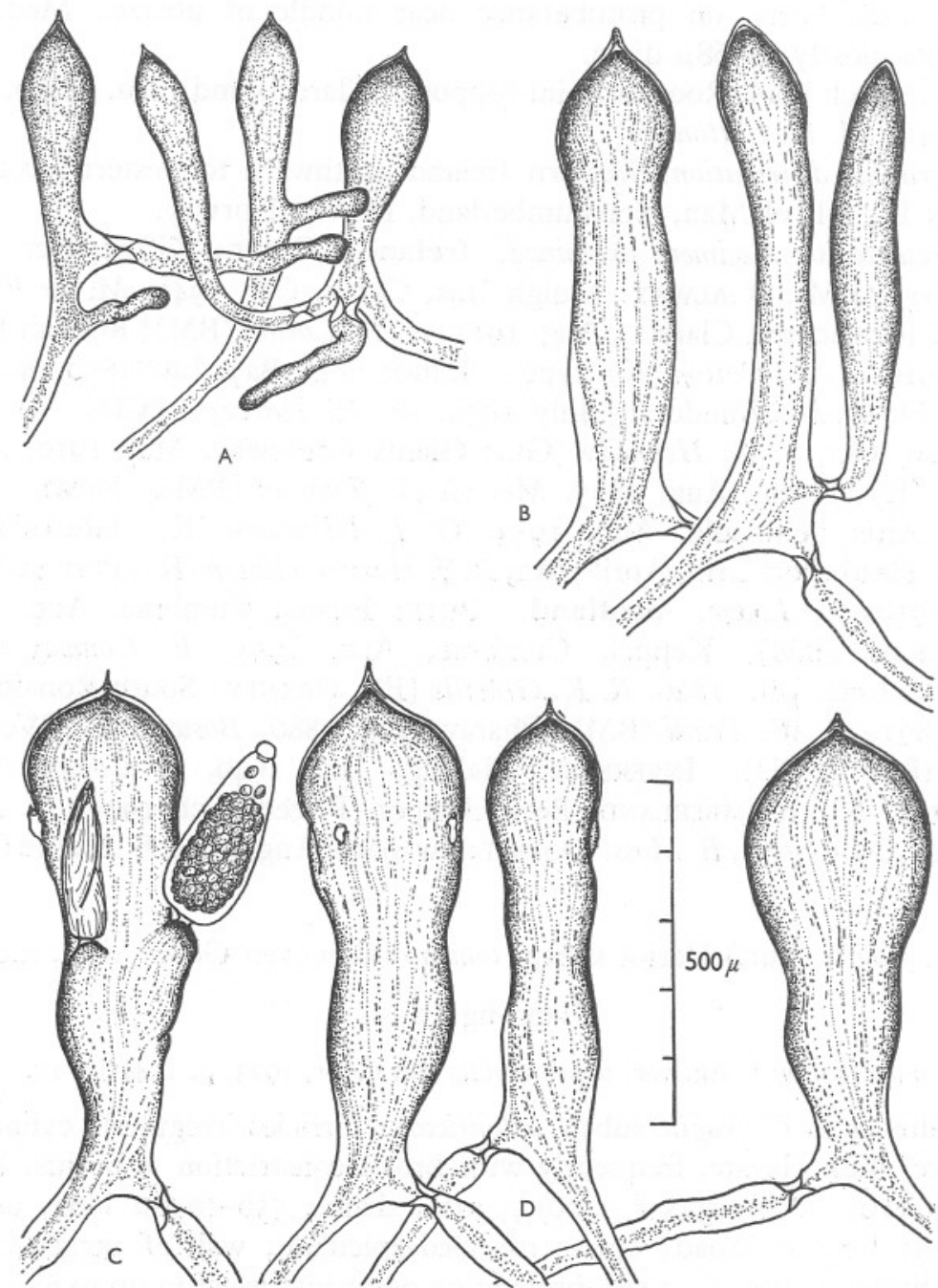

Text-fig. 2. Codium fragile subsp. tomentosoides. A, utricles from tip; B, utricles from base; C, D, utricles from middle of frond. A, D, Steer Point, Hunt; B, C, Schouwen, Holland, Aug. $1938, N$. F. N. Kamp (L). 
Representative specimens examined. England. Cornwall: Trevone, Aug. 1953, open pool in current, mid-littoral, M. A. Wilson. Devon: Bantham, July 1953, edge of large deep pool, M. A. Wilson; Yealm Estuary, near Steer Point, Nov. I939, on oyster, O.D. Hunt (BM). DORSET: Kimmeridge Ledges, Apr. 1955, C. I. Dickinson (K). Sussex: Elmer Sands, 3 miles E. of Bognor, Aug. 1954, cast up, $R$. W. F. Keag (K). Scotland. ArgYll: Loch Sween, June 1953, E. Conway (GL), Ireland. CoRK: Lough Ine, July 1950, $S$. Lodge.

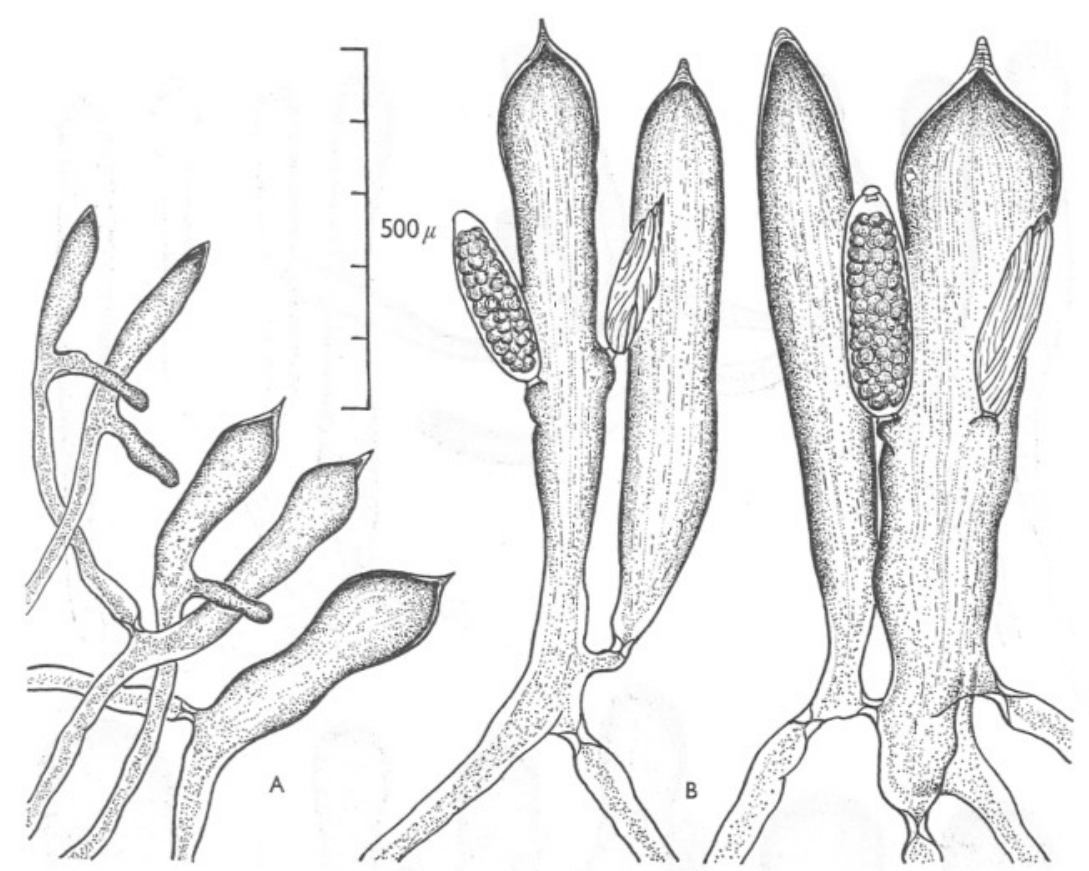

Text-fig. 3. Codium fragile subsp. tomentosoides. Lough Ine, Lodge. A, utricles from tip; B, utricles from middle of frond.

\section{Codium tomentosum Stackhouse}

(Plate I, fig. I; Text-fig. 4)

Codium tomentosum Stackhouse I797, p. xxiv. I795, p. 2I (sub Fucus tomentosus Hudson excl. syn. Linn.).

Fucus tomentosus Hudson var. marginifer Turner, I8I I, p. I.

Thallus composed of one to several erect fronds arising from broad, spongy, basal disk; fronds $20-40 \mathrm{~cm}$ high in pools, $45-60(-90) \mathrm{cm}$ high in deep water, dichotomously branched (to nine orders), dichotomies at times telescoped to give subfastigiate appearance, at other times distant (internodes 
7-8 cm long), rarely proliferous; branches mostly terete but frequently flattened at dichotomies, 3-5 $\mathrm{mm}$ diam. in lower parts, to $8 \mathrm{~mm}$ at dichotomies, attenuating to $\mathrm{I} \cdot 5-2 \mathrm{~mm}$ at apices, terminal segments often long $(5-$ I I cm). Utricles cylindrical or slightly clavate, often with hip-like enlargement near base, (65-) 100-200 (-275) $\mu$ max. diam., (420-) 500-800 ( - I050) $\mu$ long, $(3-)$ 4-7 (-9) $\times$ long as broad; apices rounded or tending to be pointed; apical wall usually moderately thickened $(-44 \mu)$, lamellate, at times introrsely umbonate and/or extrorsely bluntly pointed. Hairs (or hair

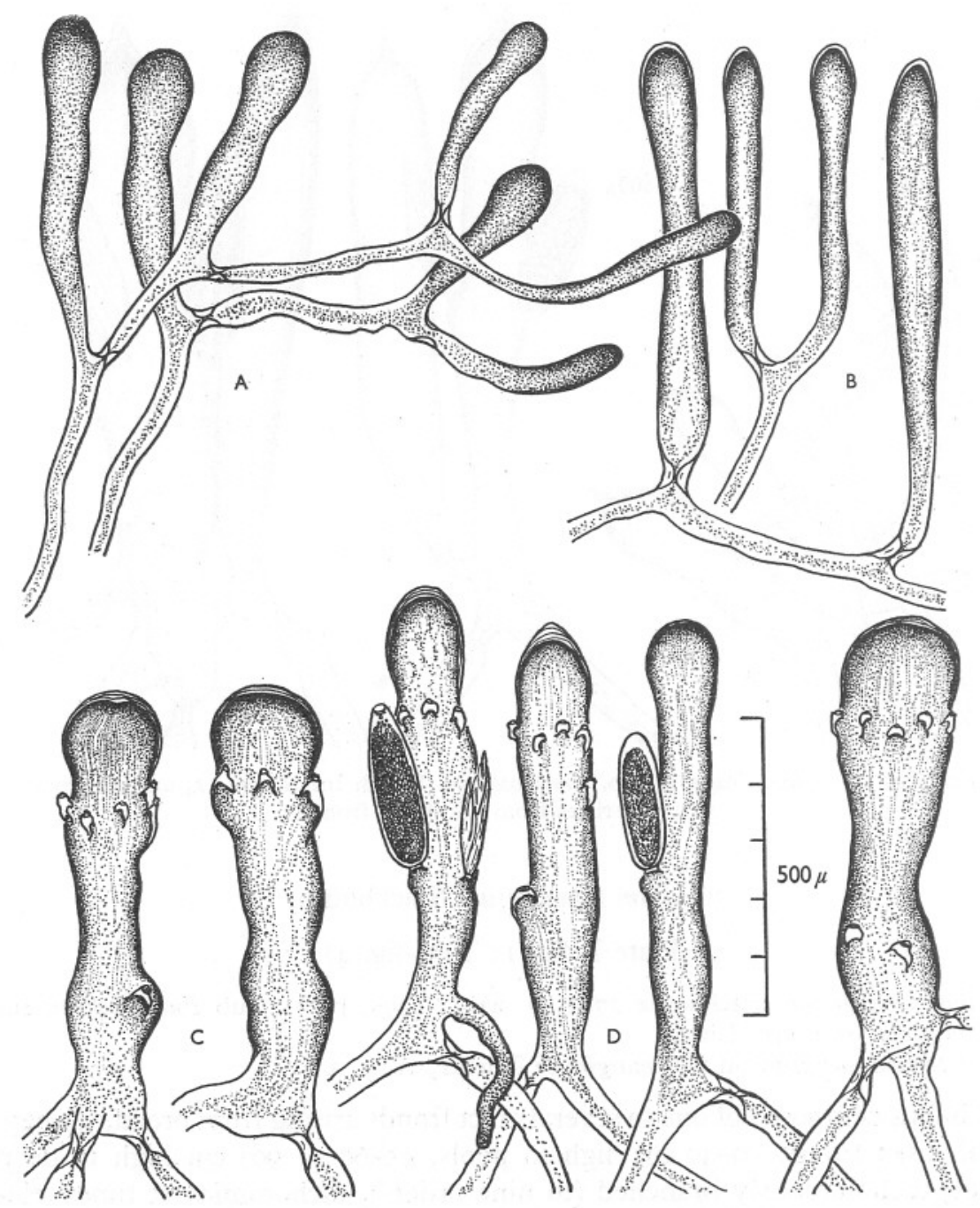

Text-fig. 4. Codium tomentosum. A, utricles from tip; B, utricles from base; C, D, utricles from middle of frond. A-C, Carna, de Valéra; D, Wembury, Ryder. 
scars) common, numerous, borne at conspicuous distance below apex (I3O$235 \mu$ ), forming collar below broadest part of utricle. Gametangia ovoid, oblong, or fusiform, 50-I IO $\mu$ diam., I65-340 $\mu$ long, one to four per utricle, each borne on prominent protuberance one-half to two-thirds distance below apex. Medullary filaments mostly $20-50 \mu$ diam.

Type. 'On the Devonshire and Cornwall Coasts: on the Long Rock between Marazion and Pensance ${ }^{1}$ plentiful. Hon. Mr. Wenman' (specimen not located). In the absence of the holotype, I have selected as neotype a specimen in the Linnean Society collected at Acton Castle, presumably by Stackhouse.

Geographic distribution. Western Ireland, Orkney Islands, southern England, Channel Islands, Netherlands southward to Morocco, Azores Islands, Algeria.

Representative specimens examined. Ireland. CoRK: Bantry Bay, July I808, Miss Hutchins (K) (type of Fucus tomentosus var. marginifer Turner). ClaRE: Kilkee, July 1833, W. H. Harvey (TCD, K, NY). Galway: Muigh Inis, Carna, Oct. I943, M. de Valéra; Renvyle Point, Jan. I83I, R. F. Shuttleworth (BM). Mayo: Clare Island, Aug. I9I I, A. D. Cotton (BM, K, NY). Sligo: Sligo Bay, July I850, Hennedy (GL). Donegal: Malin Head, July I897, M. R. Clarke (FH, NY). ANTRIM: Ballycastle, I797-98, R. Brown (BM). Scotland. ORKney Islands, $\mathcal{F}$. H. Pollexfen (BM). England. Cornwall: St Mary's, Scilly Islands, Sept. I953, E. Conway (GL); Acton Castle, Stackhouse (LINN) (neotype); King's Cove, June I799, D. Turner (BM, K); Mullion Cove, Jan. I932, Lyle (BM); Gerrans Bay, E. M. Holmes (BM); West Looe, Nov. I952, M. Parke (PL). Devon: Wembury, Oct. I953, F. G. C. Ryder (PL, UC); Salcombe, May I953, D. Ballantine (PL); Torquay, Wyatt's Algae Danmonienses no. 35 (BM, E, K, L, NY, TCD, UC); Exmouth, I864, Mrs C. A. Fohnson (BM). Dorset: Weymouth, Sept. I892, E. Batters (BM); Swanage, Aug. I894, E. Batters (BM). Sussex: Brighton, July I889, Miss Palmer (BM). Channel Islands. Guernsey, Aug. I840, Lady Mansell (BM).

A plant of $C$. tomentosum in which the dichotomous branches bear numerous simple and forked proliferations was described by Turner as a variety (marginifer) of Fucus tomentosus. This proliferous condition is rare in Codium tomentosum compared to $C$. vermilara.

\section{Codium vermilara (Olivi) Delle Chiaje}

(Plate I, fig. 2; Text-fig. 5)

Lamarckia vermilara Olivi, I792, p. 258, pl. VII.

Myrsidrum vermilara (Olivi) Rafinesque, 1810 , p. 98.

Codium vermilara (Olivi) Delle Chiaje, 1829, p. I4.

Thallus composed of one to several erect fronds arising from small, spongy, basal disk; fronds $10-45 \mathrm{~cm}$ high, closely dichotomously branched (to Io orders), often irregularly so, branches frequently bearing simple or forked proliferations; branches terete, tapering from $c .4 \mathrm{~mm}$ at base to $\mathrm{I} \cdot 5-2 \mathrm{~mm}$

1 Old spelling of Penzance (ED.). 
at tips, terminal segments usually short. Utricles clavate to pyriform, $(65-)$ 90-240 (-340) $\mu$ diam., $(330-)$ 400-650 ( - I000) $\mu$ long, $\mathrm{I} \cdot 5-4 \cdot 5(-7) \times$ long as broad; apices rounded; apical wall slightly to moderately thickened, 5 to 15 $(-50) \mu$, lamellate. Hairs (or hair scars) common, numerous, borne on shoulder of utricle 60-I IO $\mu$ below apex. Gametangia oblong to fusiform, (52-) 60-80 $(-96) \mu$ diam., $200-290 \mu$ long, one to four per utricle, each borne on protuberance one-half to two-thirds distance below apex. Medullary filaments mostly $18-45 \mu$ diam.

Type. No specimens mentioned in original description. I have selected as neotype a specimen in the Herbarium of the University of California at Berkeley distributed as Flora Exsiccata Austro-Hungarica no. 794 under the name C. tomentosum, collected by Zay at Portoré, Croatia.

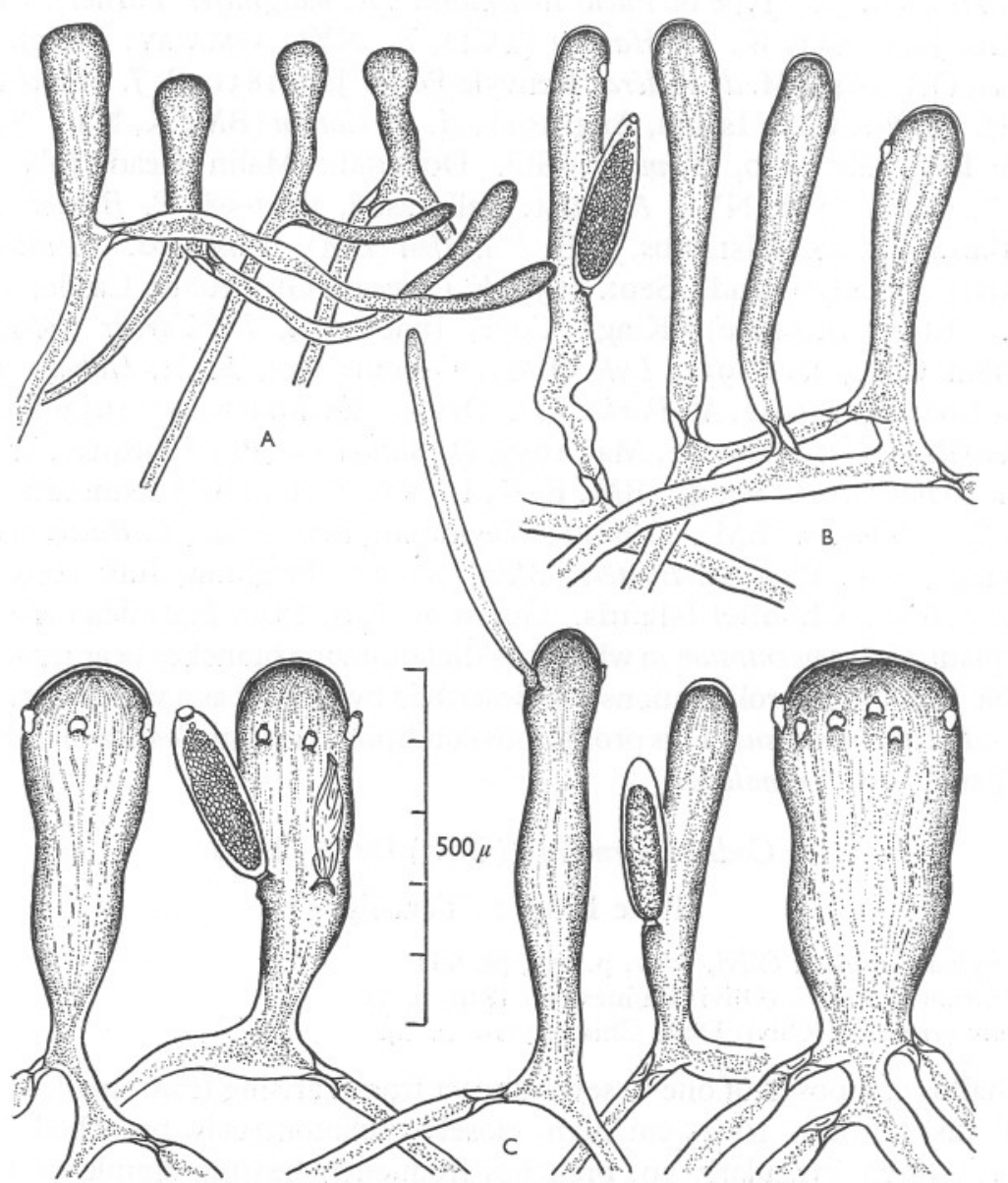

Text-fig. 5. Codium vermilara. Wembury, Ryder. A, utricles from tip; B, utricles from base; c, utricles from middle of frond. 
Geographic distribution. Ireland (Galway, Antrim), Scotland(Argyll), southern England, Channel Islands, Norway, France southward to Morocco, Mediterranean, including Adriatic.

Representative specimens examined. Ireland. Galway: Galway, McCalla (TCD). Antrim: Portrush, I835, D. Moore (K, TCD); Cushendall, W. H. Harvey (BM). Scotland. Argyll: Portnahaven, Islay, I826, f. Chalmers (BM, GL, K). England. Devon (north coast): Ilfracombe, Oct. I807, R. Hare (BM). Cornwall: Penzance, M. P. Merrifield (BM); St Michael's Mount, June I799, D. Turner (K); Acton Castle, June I798, Stackhouse (LINN); Falmouth, F. W. Smith (BM); Gerrans Bay, E. M. Holmes (BM). Devon (south coast): Wembury, Oct. I953, F. G. C. Ryder (PL, UC), Salcombe, July I94I, M. Parke (PL); Harbrick, Torbay, March I833, Mrs Griffiths (BM); Torquay, Lyon (BM); Exmouth, Miss Baker (K); Sidmouth, Nov. 1829 (TCD). Dorset: Weymouth, Dec. I9II, A. D. Cotton (K); Swanage, E. M. Holmes (US). Hants: West Cowes, Isle of Wight, Count Pouliatine (BM). Channel Islands: Jersey, F. P. Girdlestone (MrCH).

\section{Discussion}

The presence in the British Isles of a Codium with mucronate utricles was first demonstrated by Cotton (I9I2), who described C. mucronatum var. atlanticum. This entity is herein referred to $C$. fragile in accordance with the general agreement that the latter is conspecific with $C$. mucronatum. Taxonomic treatment of $C$. fragile is complicated by the following factors: (i) the species in the broadest sense may be considered a complex assemblage of populations and series of populations, some of which are morphologically homogeneous and others heterogeneous; (ii) evidence is present for hybridization or gene flow between plateaus of morphological uniformity; (iii) the species has by far the most extensive geographic distribution of any Codium, occurring on all continents; (iv) unusual physiological adaptability is implied by the variety of habitats, from the sublittoral to the midlittoral, from surf-swept rocks to quiet shell-mud flats; (v) the species has the vigour and adaptability of a weed and is spreading rapidly in such places as Scandinavia, France and Spain. A complete consideration of $C$. fragile will be presented in a forthcoming monograph of the genus. For the present account it is sufficient to state that in the British Isles there are two series of populations of mucronate Codium, each relatively uniform morphologically, which I consider best treated as subspecies of C. fragile.

The present centres of distribution of $C$. fragile are the Pacific and Subantarctic oceans. By far the greatest morphological heterogeneity occurs in Japan. In fact, almost all subspecies (geographically discrete series of morphologically uniform populations) can be matched by one or more Japanese collections. It is possible that $C$. fragile subsp. atlanticum was introduced 
from the Pacific within historical times. According to Cotton (I9I2, p. II6) it was collected at Bantry Bay by Miss Hutchins (c. 1808?). Another early collection is one made by Greville on the island of Iona in I826. Chalmers (Algae Scoticae Exsicc. no. 13, 1826) stated that Codium was unknown in Scotland before 1825 , when it was discovered on Iona by Berkeley. This subspecies seems to be spreading: Cotton (p. II9) noted that it probably was established on the Isle of Man in 1900, and the presently cited Northumberland and Swanage collections are the first published English records. (The Swanage record seems out of range and some doubt is thus raised as to the correctness of the locality.) The earliest known collection from Norway is dated I918 (Hussay near Molde, $N$. Wille, S).

Codium fragile subsp. tomentosoides seems definitely of very recent occurrence in Europe. It was first collected in Holland in 1900 (van Goor, I923, p. I33), Denmark in I920 (Rosenvinge, 1920, p. I3I), Sweden in 1938 (Brandholmen near Långő, Bohuslän, C. Engblad, S), Norway in 1952 (Bratvaer near Kristiansund, H. Printz, UC), Atlantic France in 1946 (Iles de Glénan and Concarneau, R. Lami, PC), and England apparently in 1939 (Yealm Estuary, at Steer Point, S. Devon, O. D. Hunt, BM). The place of origin seems most likely Japan.

These two subspecies of $C$. fragile are easily distinguishable anatomically. The apices of the clavate-cylindrical utricles of subsp. atlanticum are rounded, extrorsely umbonate, or provided with a very short, usually blunt mucron. The utricles of subsp. tomentosoides tend to be shorter and stouter, have a pronounced median or submedian constriction, and are sharply mucronate.

Subsequent to Cotton's demonstration of C. mucronatum (C. fragile) in the British Isles, the name C. tomentosum remained to encompass the nonmucronate dichotomous forms. That two distinct species are involved has not been recognized heretofore.

Codium tomentosum and C. vermilara differ sufficiently in habit to be distinguishable in the field with a little practice. In C. tomentosum branching is usually regularly dichotomous and the branches are often flattened at the dichotomies; the base of the thallus is thick and terminal segments are often long. In C. vermilara branching is usually somewhat irregular, often proliferous, at times divaricate, and the branches are strictly terete; the base of the thallus is not noticeably thick and terminal segments are usually short. C. tomentosum is often more robust and more distantly branched than C. vermilara. Herbarium specimens are not so readily distinguishable on the basis of habit.

Anatomically the two species are unmistakable. The position of hair scars is significant: in C. tomentosum they are well below the apex and at a constriction, so that the utricle expands above them; in C. vermilara they are usually high on the shoulders of the utricle, or if lower, never at a constriction, so that the utricle tapers rather than expands immediately above them. The average 
length/breadth ratio is greater in C. tomentosum than in C. vermilara. Thickened apices are common in both species: in C. tomentosum a blunt point is frequently formed while in $C$. vermilara the thickening is more uniform. The cylindrical or narrowly clavate utricles of $C$. tomentosum are in contrast to the clavate or pyriform utricles common in C. vermilara.

C. vermilara is common throughout the Mediterranean (including the Adriatic). In the Atlantic it extends from Morocco to France and the British Isles. Aalesund and Kristiansund in Norway constitute the most northerly records. C. tomentosum, on the other hand, is primarily an Atlantic species, occurring from the British Isles south along France, Spain, and Portugal to Morocco. It occurs in the Mediterranean only along the Algerian coast. Heretofore, $C$. tomentosum has been credited with cosmopolitan distribution, but careful study reveals that more than thirty distinct species have been confused under this name.

Separating the two non-mucronate species in the British Isles was much easier than deciding their correct names. Application of the type method was made difficult by the absence of holotypes. The earliest name applicable to a dichotomous Codium would seem to be Hudson's Spongia dichotoma (I762, p. 489) or its isonym Fucus tomentosus (1778, p. 584). However, as Linda Newton (1953, p. 403) has explained, Hudson's binomials must be considered illegitimate synonyms of $F$. elongatus $\mathrm{L}$. (the type of which is referable to Himanthalia), which Hudson cited as a synonym. This unfortunate circumstance resulted from the erroneous citation by Linnaeus of Morison's Fucus spongiosus teres ramosior viridis erectis (I699, p. 647, sect. I5, pl. 8, fig. 7), which misled Hudson to cite the Linnaean binomial. Miss Newton concluded, as I have concluded, that Codium tomentosum Stackhouse (I797) may be treated as a new name (rather than a transfer of Fucus tomentosus Hudson) in accordance with Art. 8I of the International Code of Botanical Nomenclature, inasmuch as Stackhouse explicitly excluded Fucus elongatus L. from his concept of Codium tomentosum.

In determining the application of the name Codium tomentosum Stackhouse, one is faced with the problem that Stackhouse had both non-mucronate species in hand, as shown by specimens in the Linnean Society. His description fits either species; the plant figured on Plate VII of his 'Nereis' is very likely C. vermilara. On the basis of the following considerations, however, it seems advisable to fix the application of $C$. tomentosum as delimited herein: (i) $C$. tomentosum, rather than $C$. vermilara, was the basis of treatments given by Turner (I8I I, p. I, pl. I35), Harvey (I846, pl. XcIII), and Cotton (I9I2, p. II3, pl. vIII, figs. I, 2); (ii) shifting the name $C$. tomentosum to $C$. vermilara would leave $C$. tomentosum as circumscribed herein without a name.

It is of historical interest to determine the identity of Morison's, Ray's and Hudson's plants. The two specimens in Herb. Morison (OxF), representing Fucus spongiosus teres ramosior... and Fucus spongiosus teres viridis...(I699 
p. 647, nos. 7,8 ), are both referable to C. tomentosum. The Spongia dichotomos compressa, ex viridi splendens (Ray, I724, p. 29, no. 4) in Herb. Sherard (OxF) is also representative of C. tomentosum. Hudson had both species in hand, judging from specimens at Kew, the British Museum, and Edinburgh.

Codium vermilara, occurring as it does in the Mediterranean, might be expected to have been described early. Although no authentic specimens have been located, the identity of Olivi's Lamarckia vermilara (1792), to judge from the description and figure, seems certain. While the lack of any reference to Olivi raises doubt that Codium vermilara Delle Chiaje (I829) should be considered a new combination, closer study of the rare Delle Chiaje work answers the question. It is clear from Delle Chiaje's choice of epithets in Codium that he was following Rafinesque (I8IO, p. 97), who in turn cited Olivi. Thus it seems proper to use the binomial C. vermilara (Olivi) Delle Chiaje.

\section{SUMMARY}

The dichotomous species of Codium in the British Isles are described, compared, and illustrated. These include $C$. fragile subsp. atlanticum, $C$. fragile subsp. tomentosoides, C. tomentosum and C. vermilara.

\section{REFERENCES}

Cotron, A. D., I9I2. Clare Island Survey. Marine algae. Proc. R. Irish. Acad., Vol. 3r, Part I5, 178 pp., II pls.

Delle Chiaje, S., I829. Hydrophytologiae Regni Neapolitani. 27 pp., IOO pls. Naples.

DE VALÉRA, M., I939. Some new or critical algae from Galway Bay, Ireland. $K$. fysiogr. Sällsk. Lund Förh., Bd. 9, No. 9, I4 pp.

Harvey, W. H., I846. Phycologia Britannica. Vol. I, xv, viii pp., pls. I-I20 B. London. Hudson, W., I762. Flora Anglica. 506 pp. London.

1778. Flora Anglica. 2nd ed. 690 pp. London.

LeVring, T., I937. Zur Kenntnis der Algenflora der norwegischen Westküste. Lunds Univ. Arsskr., N.F. Avd. 2, Bd. 33, No. 8 . I48 pp., 4 pls.

Morison, R., I699. Plantarum Historiae Universalis Oxoniensis Pars Tertia.... 657 pp., I66 pls. Oxford.

Newton, Lily, I931. A Handbook of the British Seaweeds. 478 pp. London.

Newton, Linda, 1953. Marine algae. Sci. Rep. fohn Murray Exped., Vol. 9, No. 5, pp. $395-420,4$ pls.

Olivi, G., I792. Zoologia Adriatica.... 334 pp., 9 pls. Bassano.

RAFINESQUE, C. S., I8ro. Caratteri di Alcuni Nuovi Generi e Nuove Specie di Animali e Pianti della Sicilia.... ro5 pp., 20 pls. Palermo.

RAY, J., I724. Synopsis Methodica Stirpium Britannicarum.... 3rd ed. 482 pp. London.

Rosenvinge, L. K., I920. Om nogle i nyere Tid indvandrede Havalger i de danske Farvande. Bot. Tidsskr., Bd. 37, pp. I25-35.

Schmid, O. C., I923. Beiträge zur Kenntnis der Gattung Codium Stackh. Bibl. bot., Stuttgart, Heft 9I, 68 pp. 

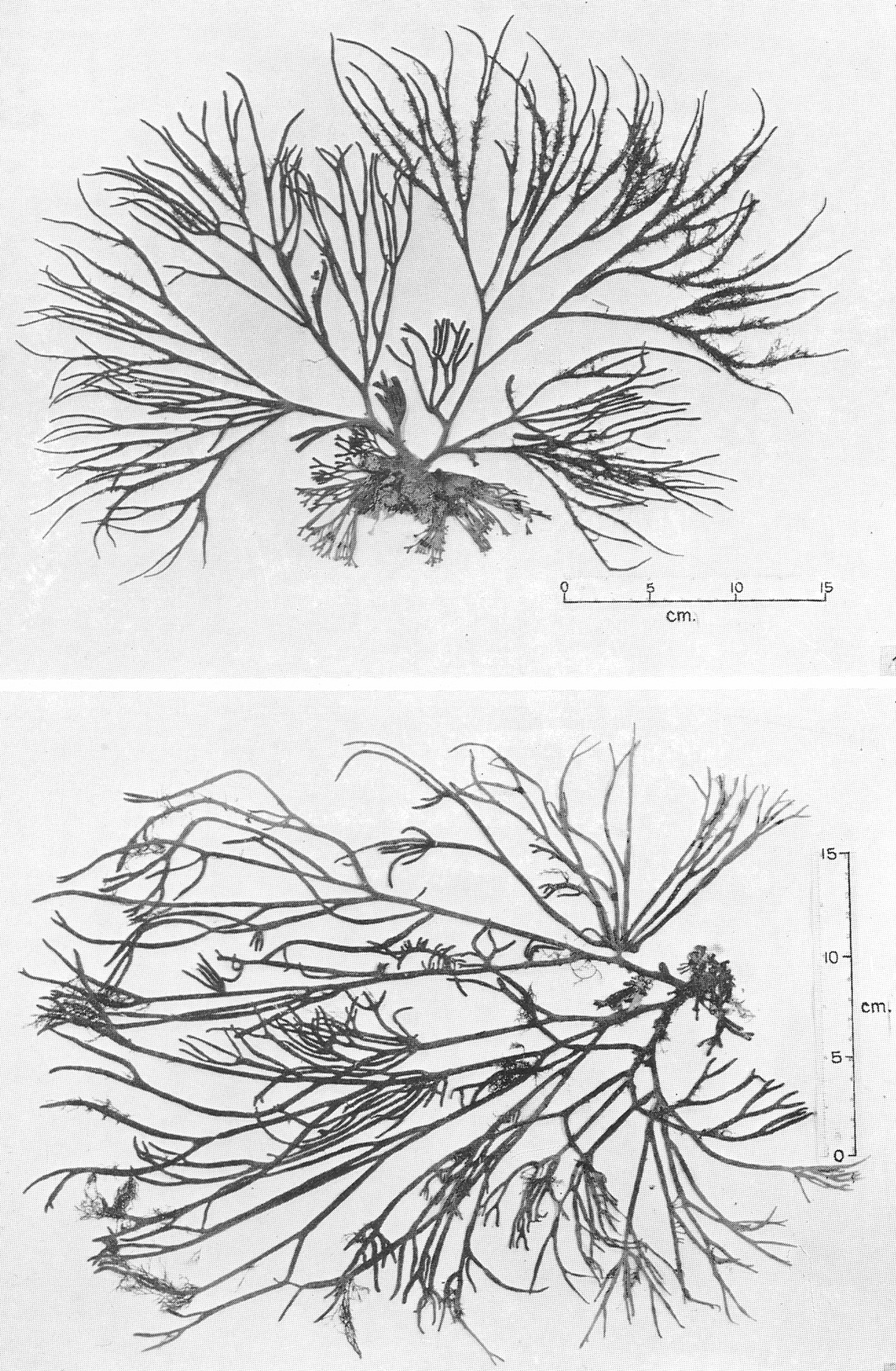

(Facing p. 576) 
Stackhouse, J., I795-I80I. Nereis Britannica.... xl, II2 pp., I7 pls. Bath.

TURNER, D., I8II. Fuci.... Vol. III. I48 pp., pls. 135-96. London.

vAN GooR, A. C. J., I923. Die holländischen Meeresalgen (Rhodophyceae, Phaeophyceae und Chlorophyceae) insbesondere der Umgebung von Helder, des Wattenmeeres und der Zuidersee. Verh. Akad. Wet. Amst., Sect. 2, Deel 23, No. 2, $232 \mathrm{pp}$.

\section{EXPLANATION OF PLATE I}

Fig. I. Codium tomentosum. Small deep pool, Church Reef, Wembury, Devon, Oct. I953, F. G. C. Ryder (UC).

Fig. 2. Codium vermilara. Large pool, mid-littoral, Church Reef, Wembury, Devon, Oct. I953, F. G. C. Ryder (UC). 